\title{
Eliminasi Bakteri Patogen pada Sayur dan Buah sebagai Bahan Baku Salad Siap Santap dengan Iradiasi Gamma
}

\section{Elimination of Pathogenic Bacteria on Vegetables and Fruits as Raw Material of Ready-to-Eat Salad by Gamma Irradiation}

\author{
Angelina Rianti ${ }^{1}$, Efendi Oulan Gustav Nata Buana ${ }^{1}$, Warsono El Kiyat ${ }^{1}$ dan \\ Harsojo $^{2}$ \\ ${ }^{1}$ Program Studi Teknologi Pangan, Fakultas Ilmu Hayati, Universitas Surya \\ Grand Serpong Mall Lt. 1 unit F8 \& F9, Jl. M.H. Thamrin Km 2.7, Tangerang, Banten 15143 \\ ${ }^{2}$ Pusat Aplikasi Isotop dan Radiasi, Badan Tenaga Nuklir Nasional \\ Jl. Lebak Bulus Raya No. 49, Jakarta 12440, Indonesia \\ E-mail : eleonora.angelina@gmail.com
}

\begin{abstract}
ABSTRAK
Salad siap santap dikategorikan sebagai produk rentan kontaminasi mikroba, sehingga untuk dapat mengurangi risiko tersebut dibutuhkan usaha eliminasi, salah satunya dengan iradiasi gamma. Tujuan penelitian ini adalah membuktikan pemanfaatan iradiasi gamma mampu atau tidak meningkatkan kualitas salad siap santap dari sisi mikrobiologisnya, menjaga sifat fisik dan kimia produk, serta menguji sensitivitas bakteri patogen terhadap iradiasi dan antibiotik. Sampel penelitian adalah sayur selada keriting (Lactuca sativa L. var. crispa) dan buah mentimun Jepang (Cucumis sativus L. var. kyuri) dengan perlakuan iradiasi 0,5 dan 1 kGy (laju iradiasi 1 kGy/jam). Dilakukan uji mikrobiologi, sifat fisik, kadar air, dan kadar serat kasar. Iradiasi gamma pada sayur selada keriting dan buah mentimun Jepang dengan dosis 0,5 dan $1 \mathrm{kGy}$ terbukti mampu meningkatkan kualitas salad siap santap dengan mereduksi kontaminasi hingga 3 siklus log mikroba, serta mempertahankan sifat fisik dan kimia produk. Sensitivitas bakteri $E$. coli sayur selada keriting terhadap iradiasi dan antibiotik lebih tinggi dibandingkan dengan buah mentimun Jepang.
\end{abstract}

Kata kunci : Iradiasi, E. coli, Bakteri, Buah, Sayur

\begin{abstract}
Ready-to-eat salad is categorized as a high-risk food. Efforts are needed to eliminate such risks, such as gamma irradiation The study aims to verify whether gamma irradiation utilization is effective to improve ready-to-eat salad safety while maintaining its physical and chemical properties and to examine pathogenic bacteria sensitivity towards irradiation and antibiotics. The samples are leaf lettuce (Lactuca sativa L. var. crispa) and Japanese cucumber (Cucumis sativus L. var. kyuri) with irradiation doses of 0.5 and $1 \mathrm{kGy}$ (dose rate $1 \mathrm{kGy} / \mathrm{h}$ ). Microbiological tests, physical examination, moisture content and crude fiber content were performed. Gamma irradiation on leaf lettuce and Japanese cucumber with doses of 0.5 and $1 \mathrm{kGy}$ was proven to improve the quality of ready-to-eat salad by reducing contamination up to 3 microbial log cycles, while maintaining its physical and chemical properties. The sensitivity of $E$. coli bacteria from leaf lettuce to irradiation and antibiotic is higher compared with Japanese cucumber.
\end{abstract}

Keywords : Irradiation, E. coli, Bacteria, Fruits, Vegetables

\section{PENDAHULUAN}

Produk salad siap santap semakin banyak diminati oleh masyarakat karena kandungan gizinya yang kaya akan serat, karbohidrat, vitamin, dan mineral [1]. Penjualan produk dengan kategori pangan sehat juga terbukti meningkat sebesar $15 \%$ di Asia Pasifik, dan hal ini menunjukkan bahwa saat ini konsumen tertarik pada produk yang segar, natural, dan diproses secara minimal untuk menjaga kesehatan mereka [2]. Sibuknya kegiatan sehari-hari masyarakat khususnya di kota-kota besar juga mengakibatkan konsumen akan lebih memilih produk siap santap. Perkembangan produk-produk siap santap/readyto-eat juga terus meningkat selama beberapa tahun belakangan [3].

Salad siap santap adalah salah satu contoh produk yang diproses secara minimal. Produk ini dikategorikan sebagai produk berisiko tinggi 
karena proses pengolahannya yang minim [4]. Kontaminasi pada salad siap santap akan berakibat pada timbulnya penyakit untuk manusia (foodborne disease). Penyebab terbesar dari kasus keracunan pangan adalah kontaminasi oleh bakteri patogen, seperti Salmonella dan Escherichia coli. Kontaminasi bakteri patogen dapat menyebabkan sakit kepala, kram perut, demam, diare, hingga kematian [5]. Keracunan yang disebabkan oleh produk-produk segar, siap santap, dan diproses minimal menyumbang 20\% dari total kasus keracunan pangan [6].

Kontaminasi pada buah dan sayur segar sebagai bahan baku salad siap santap perlu diperhatikan khususnya pada bakteri Salmonella dan E. coli [7]. Terdapat beberapa cara untuk mencegah kontaminasi mikroba pada salad siap santap, seperti proses pemanasan, penggunaan pembersih kimia, atau aplikasi iradiasi. Namun, penggunaan pemanasan dan bahan kimia dapat menyebabkan perubahan pada tekstur, komposisi gizi produk, dan adanya risiko residu kimia [1]. Salah satu perlakuan yang mampu mengeliminasi bakteri patogen dan bersifat aman adalah proses iradiasi dengan sinar gamma [8].

Proses iradiasi gamma dengan dosis rendah, yakni di bawah 2 kGy tidak memberikan perubahan fisik sayur dan buah. Iradiasi dengan dosis iradiasi gamma 2 dan 3 kGy pada sayur dan buah terbukti memberikan perubahan kelayuan dan warna menjadi kuning [26].

Iradiasi gamma yang mengenai dinding sel sayur dan buah dapat berdampak pada interaksi molekul air dan proses radiolisis sehingga kadar air bahan mungkin berubah [9]. Komponen struktural utama dalam dinding sel sayur dan buah adalah selulosa [10]. Proses iradiasi gamma dapat merubah struktur kompleks selulosa menjadi lebih sederhana [11]. Analisis serat kasar dilakukan untuk menghitung serat kompleks yang tidak dapat dihidrolisis asam, basa, dan panas, seperti selulosa [30].

Pemanfaatan iradiasi gamma diharapkan dapat mengeliminasi bakteri patogen yang ada di dalam sayur dan buah tanpa diikuti perubahan fisik, kadar air, dan kadar serat kasar produk.

\section{BAHAN DAN METODE}

\section{Bahan}

Sampel yang digunakan adalah bahan baku salad siap santap, yakni sayur selada keriting ( $L$. sativa L. var. crispa) dan buah mentimun Jepang (C. sativus L. var. kyuri) yang diperoleh dari pasar swalayan di kawasan Gading Serpong, Tangerang, Banten. Selain itu, bahan lain yang digunakan adalah media agar nutrien (Oxoid), media agar Hektoen Entero (Merck), media agar MacConkey (Oxoid), media agar Eosin Methylene Blue (Oxoid), media agar Mueller Hinton (Pronadisa), media agar Simmons Citrate (Oxoid), Tetrathionate Broth (Difco), Tryptone Broth (Oxoid), MR-VP Broth (Oxoid), larutan iodin dari campuran kristal iodin (Merck) dan potasium iodida (Merck), pepton (Difco), reagen Kovacs, reagen methyl red, reagen Barrit A dan $\mathrm{B}$, alkohol $70 \%, \mathrm{H}_{2} \mathrm{SO}_{4} 1,25 \%$, $\mathrm{NaOH} 3,25 \%$, akuades, plastik LDPE berukuran 15 mikron, kertas aluminum foil, cawan aluminum foil disposable, kertas saring Whatman, es batu, spiritus, kain kasa, serta kapas.

\section{Analisis kontaminasi mikroba}

Analisis total kontaminasi mikroba yang dilakukan adalah analisis Angka Lempeng Total (ALT) [12], bakteri koliform [13], dan deteksi Salmonella [14]. Proses pengujian dilakukan dengan metode spread plate pada agar nutrien (Oxoid), agar MacConkey (Oxoid), dan agar Hektoen Entero (Merck), lalu diinkubasi selama 24-48 jam pada 25 . Analisis dilakukan dua kali pengulangan.

\section{Proses iradiasi}

Iradiasi gamma sampel dilakukan di Iradiator Panorama Serba Guna (IRPASENA) dengan dosis 0; 0,5; dan $1 \mathrm{kGy}$ pada laju dosis 1 kGy/jam. Sampel kemudian disimpan di lemari pendingin dengan suhu $4 \pm 1^{\circ} \mathrm{C}$.

\section{Perhitungan nilai $\mathbf{D}_{\mathbf{1 0}}$}

Koloni bakteri E. coli dibuat menjadi suspensi dalam akuades steril dan diiradiasi dengan dosis $0 ; 0,1 ; 0,2 ; 0,3$; dan 0,4 kGy. Kemudian, suspensi diinokulasi ke dalam agar nutrien (Oxoid) dengan pengenceran $10^{-1}-10^{-5}$ dan diinkubasi pada suhu kamar selama 24-48 jam kemudian koloni bakteri dihitung dengan metode ALT [12]. Analisis dilakukan dua kali pengulangan.

\section{Pengukuran sensitivitas $E$. coli terhadap beberapa antibiotik}

Sensitivitas bakteri E. coli terhadap antibiotik ditentukan dengan metode kertas 
cakram pada media agar Mueller Hinton (Pronadisa) sesuai dengan metode Harsojo dan Sari [13].

\section{Penentuan kadar air}

Kadar air sampel kontrol dan iradiasi ditentukan dengan prinsip analisis metode oven sesuai dengan prosedur SNI 01-2891-1992 [15]. Analisis dilakukan dua kali pengulangan.

\section{Penentuan kadar serat kasar}

Kadar serat kasar dapat diukur menggunakan prinsip ekstraksi dengan asam basa sesuai dengan prosedur SNI 01-2891-1992 [15]. Analisis dilakukan dua kali pengulangan.

\section{HASIL DAN PEMBAHASAN}

\section{Kontaminasi mikroba (ALT)}

Total kontaminasi bakteri pada sampel yang telah dan belum diiradiasi dapat dilihat pada Tabel 1. Perlakuan iradiasi dengan dosis hingga $1 \mathrm{kGy}$ dapat menurunkan 3 siklus log mikroba pada penyimpanan hari ke-0. Belum ada batas kontaminasi mikroba dari SNI yang ditentukan untuk produk sayur dan buah segar. Namun, produk siap santap memiliki batas kontaminasi mikroba untuk dikategorikan baik dan sanitasinya terjaga sebesar kurang dari $10^{6} \mathrm{CFU} / \mathrm{g}$ [16; 17]. Oleh karena itu, sayur selada keriting yang belum diiradiasi dapat dinyatakan telah melewati batas kualitas tersebut, sedangkan buah mentimun Jepang masih berada pada ambang batas.

Tabel 1. Total kontaminasi mikroba pada sayur selada keriting dan buah mentimun Jepang penyimpanan hari ke-0

\begin{tabular}{lcc}
\hline & $\begin{array}{c}\text { Dosis } \\
\text { iradiasi } \\
(\mathrm{kGy})\end{array}$ & $\begin{array}{c}\text { Total kontaminasi } \\
\text { mikroba } \\
(\mathrm{CFU} / \mathrm{g})\end{array}$ \\
\hline Selada keriting & 0 & $7,20 \times 10^{6}$ \\
& 0,5 & $3,32 \times 10^{5}$ \\
& 1 & $1,65 \times 10^{4}$ \\
\hline Mentimun Jepang & 0 & $7,75 \times 10^{5}$ \\
& 0,5 & $3,60 \times 10^{4}$ \\
& 1 & $1,52 \times 10^{4}$ \\
\hline
\end{tabular}

Penyimpanan produk dilakukan selama 3 hari pada suhu $4 \pm 1$. Pada hari penyimpanan ke3 , kontaminasi total mikroba pada sayur selada keriting dan mentimun Jepang mencapai 1,74 $\times$ $10^{7} \mathrm{CFU} / \mathrm{g}$ dan $1,86 \times 10^{7} \mathrm{CFU} / \mathrm{g}$. Perlakuan iradiasi sebesar 0,5 dan 1 kGy dapat menjaga kontaminasi total mikroba agar tetap di bawah $10^{7}$ CFU/g meskipun telah disimpan selama 3 hari.

Produk sayur dan buah segar yang sudah dipotong dan siap santap rentan terhadap kontaminasi mikroba. Produk-produk segar ini berada pada urutan kedua jenis produk yang paling rentan terhadap kontaminasi setelah produk seafood [18]. Proses yang dimulai dari panen hingga penanganan produk akhir memungkinkan sayur dan buah segar untuk terkontaminasi oleh bakteri patogen.

Proses minimal pada produk buah dan sayur segar menyebabkan produk menjadi berisiko karena bagian sel pelindung alami dari buah dan sayur telah dihilangkan saat proses pengupasan (untuk buah) dan pemotongan. Mikroorganisme yang mungkin mengkontaminasi produk buah dan sayur segar yang diproses minimal adalah bakteri pembentuk spora, bakteri non pembentuk spora, virus, dan parasit. Beberapa studi hasil fakta kasus keracunan sayur dan buah segar yang terjadi menunjukkan mayoritas kontaminasi berasal dari bakteri non pembentuk spora (55\%), seperti Salmonella dan E. coli [19].

\section{Kontaminasi mikroba (koliform)}

Data uji kontaminasi bakteri koliform dapat dilihat pada Tabel 2. Jumlah kontaminasi bakteri koliform pada sayur selada keriting dan buah mentimun Jepang menandakan bahwa sanitasi produk masih belum terjaga. Kontaminasi mikroba koliform dapat mencapai 1,95 × $10^{6}$ $\mathrm{CFU} / \mathrm{g}$ pada hari penyimpanan ke-0 dan meningkat hingga 1,09 × $10^{7} \mathrm{CFU} / \mathrm{g}$ pada hari penyimpanan ke-3.

Tabel 2. Total kontaminasi mikroba jenis koliform pada sayur selada keriting dan buah mentimun Jepang penyimpanan hari ke-0

\begin{tabular}{lcc}
\hline & $\begin{array}{c}\text { Dosis } \\
\text { iradiasi } \\
(\mathrm{kGy})\end{array}$ & $\begin{array}{c}\text { Total kontaminasi } \\
\text { mikroba } \\
(\mathrm{CFU} / \mathrm{g})\end{array}$ \\
\hline Selada & 0 & $1,95 \times 10^{6}$ \\
keriting & 0,5 & $3,57 \times 10^{4}$ \\
& 1 & $2,45 \times 10^{3}$ \\
\hline Mentimun & 0 & $3,68 \times 10^{5}$ \\
Jepang & 0,5 & $1,68 \times 10^{4}$ \\
& 1 & $1,50 \times 10^{2}$ \\
\hline
\end{tabular}

Keberadaan bakteri koliform menunjukkan adanya kontaminasi air yang selanjutnya ikut mengkontaminasi produk. Kontaminasi air pada 
sayur dan buah dapat berasal dari air irigasi selama proses panen, tanah tempat pertumbuhan, pupuk yang digunakan, maupun berasal dari air yang digunakan untuk pencucian [20]. Perlakuan iradiasi gamma dengan dosis 0,5 dan $1 \mathrm{kGy}$ dapat membantu mengeliminasi bakteri koliform hingga penurunan sebesar 3 siklus log dari jumlah awalnya.

\section{Kontaminasi mikroba (Salmonella)}

Hasil uji bakteri Salmonella pada sampel sayur selada keriting dan buah mentimun Jepang adalah negatif. Hasil ini sesuai dengan ketentuan/syarat pada dokumen SNI 7388:2009, ISO 6579:2002 [7], serta dokumen BPOM RI HK.00.06.1.52.4011 [21].

\section{Nilai $\mathbf{D}_{10}$}

Bakteri E. coli dari sampel buah mentimun Jepang memiliki nilai $\mathrm{D}_{10}$ yang lebih tinggi, sehingga bersifat lebih resisten terhadap iradiasi gamma dibandingkan dengan bakteri E. coli dari sampel sayur selada keriting (Tabel 3). Perbedaan nilai $\mathrm{D}_{10}$ dapat karena adanya perbedaan pada sumber isolat bakteri sehingga materi genetiknya berbeda-beda dan menyebabkan perbedaan kemampuan adaptasi bakteri terhadap iradiasi gamma. Selain itu, faktor kondisi lingkungan sekitar, seperti ketersediaan oksigen dan suhu iradiasi juga mampu mempengaruhi nilai $\mathrm{D}_{10}$. Nilai tersebut sangat berguna untuk dekontaminasi bakteri. Kemampuan pengionan sinar gamma memungkinkannya membunuh bakteri dalam jumlah besar dengan menyebabkan perubahan kimia pada sel bakteri. Perubahan kimia ini merupakan penghambat sintesis DNA dengan mengganggu proses duplikasi sel dan reproduksi bakteri [13].

Tabel 3. Nilai $\mathrm{D}_{10}$ E. coli sayur selada keriting dan buah mentimun Jepang

\begin{tabular}{lc}
\hline Sampel & Nilai $\mathrm{D}_{10}(\mathrm{kGy})$ \\
\hline Selada keriting & 0,14 \\
Mentimun Jepang & 0,16 \\
\hline
\end{tabular}

\section{Sensitivitas antibiotik}

Pengujian sensitivitas bakteri E. coli dilakukan terhadap beberapa antibiotik yang umum, yakni amoksisilin, tetrasiklin, dan sefoksitin [13]. Pengujian dilakukan dengan mengukur diameter zona bening yang terbentuk di sekitar antibiotik, yang disebut sebagai zona inhibisi [22]. Bakteri E. coli dari sampel sayur selada keriting bersifat lebih sensitif terhadap ketiga jenis antibiotik dibandingkan dengan bakteri E. coli dari sampel buah mentimun Jepang (Tabel 4).

Tabel 4. Sensitivitas bakteri E. coli terhadap antibiotik

\begin{tabular}{lccc}
\hline \multirow{2}{*}{ Sampel } & \multicolumn{3}{c}{ Zona Inhibisi Antibiotik (mm) } \\
\cline { 2 - 4 } & Amoksisilin & Tetrasiklin & Sefoksitin \\
\hline $\begin{array}{l}\text { Selada } \\
\text { keriting }\end{array}$ & 26 & 28 & 18 \\
$\begin{array}{l}\text { Mentimun } \\
\text { Jepang }\end{array}$ & $<10^{*}$ & 28 & $14^{*}$ \\
\hline
\end{tabular}

Sensitif ; * Resisten

Mekanisme antibiotik tetrasiklin bekerja dengan menghambat proses sintesis protein [23] dengan mekanisme menghalangi pengikatan aminoasil t-RNA di dalam kompleks m-RNA sehingga menghalangi penggabungan asam amino di rantai peptida [24]. Antibiotik amoksisilin dan sefoksitin memiliki mekanisme kerja yang mirip dengan antibiotik penisilin, yaitu dengan bertindak melalui penghambatan sintesis dinding sel yang menyebabkan kematian bakteri [25].

\section{Analisis sifat fisik}

Perlakuan iradiasi gamma terhadap sampel sayur dan buah segar diharapkan tidak mengubah sifat fisik dari produk. Penelitian Suciati [26] menunjukkan bahwa buah dan sayur dengan penampakan fisik yang tidak diinginkan adalah adanya perubahan warna menjadi kekuningan ataupun terjadi pelayuan akibat iradiasi dengan dosis 2 dan $3 \mathrm{kGy}$. Tidak terdapat perubahan sifat fisik berupa perubahan warna atau kelayuan antara sampel perlakuan iradiasi gamma dengan menggunakan dosis 0,5 maupun $1 \mathrm{kGy}$ dan sampel yang tidak diberi perlakuan iradiasi gamma. Hasil tersebut menunjukkan bahwa sayur selada keriting dan buah mentimun Jepang memiliki stabilitas yang baik dalam menjaga pigmen warna pembentuknya selama proses iradiasi gamma. Perlakuan iradiasi gamma dengan dosis rendah, yakni $1 \mathrm{kGy}$ atau kurang tidak akan memberikan perubahan pada sayur (fresh-cut vegetable). Penggunaan dosis iradiasi gamma lebih besar dari 1 kGy dapat berdampak pada perubahan warna buah mentimun yang tidak diinginkan, yakni menjadi kekuningan [27].

\section{Analisis kadar air dan kadar serat kasar}

Kadar air merupakan komponen penyusun utama pada selada keriting dan mentimun Jepang. 
Analisis menunjukkan bahwa kadar air pada kedua sampel tidak mengalami perubahan kadar air yang signifikan setelah diberikan perlakuan iradiasi gamma 0,5 dan $1 \mathrm{kGy}$ (Tabel 5).

Tabel 5. Hasil analisis kadar air

\begin{tabular}{lcc}
\hline Sampel & Dosis (kGy) & Kadar air (\%) \\
\hline Selada keriting & 0 & 94,75 \\
& 0,5 & 94,72 \\
& 1 & 94,97 \\
\hline Mentimun Jepang & 0 & 96,40 \\
& 0,5 & 96,56 \\
& 1 & 96,75 \\
\hline
\end{tabular}

Pemberian dosis iradiasi gamma yang tinggi bahkan mencapai 10 kGy tidak akan memberikan perubahan terhadap kadar air sampel [28]. Sampel sayur kachri yang diiradiasi dengan dosis 2,5; 5,0; dan 7,0 kGy tidak mengalami perubahan kadar air [29]. Kadar serat kasar merupakan perhitungan atas residu yang tersisa selama reaksi dengan asam, basa, dan pemanasan. Residu bahan pangan yang tersisa setelah reaksi dengan asam, basa, dan pemanasan sebesar 97\% adalah selulosa. Selulosa tersebut merupakan karbohidrat kompleks yang menjadi komponen struktural utama dalam dinding sel pada sayur-sayuran dan buah-buahan [30].

Tabel 6. Hasil analisis kadar serat kasar

\begin{tabular}{lcc}
\hline Sampel & $\begin{array}{c}\text { Dosis } \\
(\mathrm{kGy})\end{array}$ & $\begin{array}{c}\text { Kadar serat } \\
\text { kasar (\%) }\end{array}$ \\
\hline Selada keriting & 0 & 1,41 \\
& 0,5 & 1,44 \\
& 1 & 1,63 \\
\hline Mentimun Jepang & 0 & 0,20 \\
& 0,5 & 0,47 \\
& 1 & 0,21 \\
\hline
\end{tabular}

Perlakuan iradiasi gamma dengan dosis 0,5 dan 1 kGy tidak menghasilkan perubahan kadar serat kasar pada sayur selada keriting maupun buah mentimun Jepang (Tabel 6). Kadar serat kasar tidak memiliki kecenderungan untuk meningkat atau menurun ketika diberi perlakuan iradiasi gamma. Perlakuan iradiasi gamma pada komoditas sayur dan buah dengan dosis tidak melebihi 10 kGy tidak memberikan perubahan dalam seluruh kandungan nutrisi yang diujikan menggunakan uji proksimat [31].

\section{KESIMPULAN}

Pemanfaatan iradiasi gamma pada sayur selada keriting (Lactuca sativa L. var. crispa) dan buah mentimun Jepang (Cucumis sativus L. var. kyuri) dengan dosis 0,5 dan $1 \mathrm{kGy}$ (laju iradiasi gamma $1 \mathrm{kGy} / \mathrm{jam}$ ) terbukti mampu untuk meningkatkan kualitas produk salad siap santap dengan mengeliminasi bakteri patogen tanpa mengubah sifat fisik, kadar air, dan kadar serat kasar dari sayur dan buah. Tidak ditemukan kontaminasi bakteri Salmonella pada sampel. Bakteri E. coli yang berasal dari sampel sayur selada keriting bersifat lebih sensitif terhadap iradiasi dan antibiotik dibandingkan dengan bakteri E. coli yang berasal dari sampel buah mentimun Jepang.

\section{UCAPAN TERIMA KASIH}

Penulis mengucapkan terima kasih kepada PAIR-BATAN dan Laboratorium Universitas Surya yang telah membantu penelitian ini melalui fasilitas yang disediakan.

\section{DAFTAR PUSTAKA}

[1] Chun, H., Kim, J., Song, K.B., Inactivation of Foodborne Pathogens in Ready-to-eat Salad Using UV-C Irradiation, Food Sci. Biotechnol, 19, 2, 547-551, 2010.

[2] Nielsen, A.C., We Are What We Eat: Healthy Eating Trends Around The World, Nielsen Global Health and Wellness Report, 2015.

[3] Moshak, Z., Langroodi, A.M., Fathabad, A.E., Ilkhanipoor, A., Microbiological Quality of Ready-to-eat Foods of Tehran Province, African Journal of Food Science, 9, 5, 257-261, 2015.

[4] Hannan, A., Rehman, R., Saleem, S., Khan, M.U., Qamar, M.U., Azhar, H., Microbiological Analysis of Ready-toeat Salads Available at Different Outlets in Lahore, Pakistan, International Food Research Journal, 21, 5, 1797-1800, 2014 
[5] Garg, N., Abdel-Aziz, S.M., Aeron, A., Microbes in Food and Health, Cham: Springer, 2016.

[6] World Health Organization, WHO's First Ever Global Estimates of Foodborne Diseases Find Children Under 5 Account for Almost One Third of Deaths, 2015.

[7] Badan Standardisasi Nasional, Batas Maksimum Cemaran Mikroba dalam Pangan (SNI 7388:2009), Jakarta, Badan Standardisasi Nasional, 2009.

[8] International Atomic Energy Agency, The Development of Irradiated Foods for Immuno-Compromised Patients and other Potential Target Groups, Report of the First Research Coordination Meeting, 23 - 27 August 2010, Austria, 2010.

[9] Rai, V.R., Bai, J.A., Food Safety and Protection, Boca Raton: CRC Press, 2017.

[10] Hillman, H., The New Kitchen Science (3rd ed.), New York: Houghton Mifflin Company (2003).

[11] Wilkinson, V.M., Gould, G.W., Food Irradiation: A Reference Guide, Oxford: Woodhead Publishing Limited, 1998.

[12] Badan Pengawas Obat Dan Makanan Republik Indonesia, Pengujian Mikrobiologi Pangan. InfoPom, 9, 2, 2008.

[13] Harsojo, Sari, S.Y., Bacterial Diversity in Buffalo Meat and Bowel from Traditional Market and The Sensitivity of Some Bacteria to Irradiation and Antibiotics, Atom Indonesia, 31, 2, 7985, 2015.

[14] Feng P., Bam, Salmonella, Bacteriological Analytical Manual, 2009.

[15] Badan Standardisasi Nasional, Cara Uji Makanan dan Minuman (SNI 01-2891-
1992), Jakarta, Badan Standardisasi Nasional, 1992.

[16] Center For Food Safety, Microbiological Guidelines for Food: for Ready-to-eat Food in General and Specific Food Items, Hong Kong, Center for Food Safety, 2014.

[17] Nsw Food Authority, Microbiological Quality Guide for Ready-to-eat Foods, Newington, Food Authority Australia, 2009.

[18] Sizer, F.S., Whitney, E., Nutrition: Concepts and Controversies (13th ed.), Belmont: Cengage Learning, 2014.

[19] James, J., Microbial Hazard Identification in Fresh Fruit and Vegetables, New Jersey, John Wiley \& Sons, 2008.

[20] Yani, A.V., Hasbi, Priyanto, G., Pambayun, R., Wijaya, A., Tingkat Kontaminasi Mikroba dan Residu Pestisida pada Sayuran Segar, Proceeding National Seminar of Suboptimal Area, Palembang, 2016.

[21] Badan Pengawas Obat Dan Makanan Republik Indonesia, Penetapan Batas Maksimum Cemaran Mikroba dan Kimia dalam Makanan (Nomor HK.00.06.1.52.4011), Jakarta, Badan Pengawas Obat dan Makanan, 2009.

[22] Jones, M., Fosbery, R., Gregory, J., Taylor, D., Biology Coursebook (4th ed.), Cambridge: Cambridge University Press, 2014.

[23] Gottlieb, D., Shaw, P.D., Antibiotics: Volume I Mechanism of Action, Illinois, Springer, 2013.

[24] Mouton, J.W., Nabuurs-Franssen, M.H., 'Omadacycline', In: Grayson, M.L. (ed.) Kucer's The Use of Antibiotics (p.2002), Boca Raton: CRC Press, 2012.

[25] Clementi, F., Fumagalli, G., General Molecular Pharmacology: Principle of 
Drug Action, New Jersey: John Wiley \& Sons, 2015.

[26] Suciati, A., Analisa Kandungan Logam Berat $(\mathrm{Pb}, \mathrm{Cd}$, dan $\mathrm{Hg})$ dan Iradiasi Gamma Co-60 pada Sayuran Organik, Thesis, Universitas Islam Negeri Syarif Hidayatullah, Jakarta, 2013.

[27] Fan, X., Niemira, B.A., Prakash, A., Irradiation of Fresh Fruits and Vegetables, Food Technology, 3, 8, 3643, 2008.

[28] Rodrigues, S., Fernandes, F.A.N., Advances in Fruit Processing Technologies, Boca Raton, CRC Press, 2012.
[29] Nathawat, N.S., Joshi, P., Chhipa, B.G., Hajere, S.., Goyal, M. Sahu, M.Pp., Singh, G., Effect of Gamma Radiation on Microbial Safety and Nutritional Quality of Kachri (Cucumis callosus, Journal of Food Science and Technology, 50, 4, 723-730, 2013.

[30] Pomeranz, Y., Meloan, C.E., Food Analysis: Theory and Practice (3rd ed.), New York, Chapman \& Hall, 2013.

[31] Bamidele, O.P., Akanbi, C.T., Effect of Gamma Irradiation on Physicochemical Properties of Stored Pigeon Pea Flour, Food Research \& Nutrition, 1, 5, 377383, 2013. 
Jurnal Ilmiah Aplikasi Isotop dan Radiasi

A Scientific Journal for The Applications of Isotopes and Radiation

pISSN 1907-0322

Vol. 14 No. 1 Juni 2018

eISSN 2527-6433 